UDC: $316.621-053.6(477)$

DOI: https://doi.org/10.24195/2414-4665-2017-6-1

\author{
Olena Troitska, \\ PhD (Candidate of Philosophical Sciences), \\ associate professor, doctoral student, \\ of National pedagogical Dragomanov University, \\ 9, Pirohova Str., Kyiv, Ukraine \\ Kateryna Averina, \\ PhD (Candidate of Pedagogical Sciences), \\ associate professor, Department of Social Work, \\ Social Science and Preschool Education, \\ Melitopol Bohdan Khmelnitskyi State Pedagogical University, \\ 20, Getmanska Str., Melitopol, Ukraine
}

\title{
SOCIAL ACTIVENESS OF YOUNG PEOPLE: DIALOGICAL SUPPORT IN THE CULTURAL AND EDUCATIONAL SPACE
}

The relevance of the research is determined by the problematic situation in the cultural and educational space due to the fact that the activeness of young people as a subject of this space is incredibly increasing and the level of understanding of its significance, its essence, opportunities and limits has been insufficient. Activeness as a phenomenon is of a key importance in humanities where it is interpreted multiplicably and appears comparatively as the one identified with other phenomena. The review of scientific publications does not require only the correct definition of the essence of social activeness, but also the determination of the impact of cultural and educational space factors on its formation, which should include the dialogue as an informative and existential interaction of subjects aimed at understanding. Based on the interdisciplinary methodology, phenomenological approach, research methods (interpretation, comparative analysis, synergetic method, etc.) and techniques of collecting empirical data (testing, survey, observation, introspection, etc.) the dependence of the development of students' social activeness on the involvement in the development of dialogical strategies of cultural and educational space has been determined. The dialogical support is presented as an enhancement of social activeness (a set of individual's efforts to transform oneself and the society) that occurs according to the components of the subject's actions, the stages of starting up social activity, different levels of the society development, the growth of the level of individual freedom.

Keywords: interaction, action, activity, understanding, social, communication, subject, values.

\section{Introduction}

The relevance of the research is explained by the complexity of the situation observed in the modern cultural and educational space of world communities, in which there is an increasing people's desire for freedom, subjectivity, on the one hand, and on the other hand, an increase in the volume of cultural diversity which requires the search for the consent of the subjects, their joint constructive activity. That is why it is the justification of the methodological choice of ways of full, comprehensive, harmonious improvement of the person and his/her being which has recently become the most important issue of modern science obliged to form person's stable perspectives and senses of various cultural interests and values realization. The filling of the educational environment with the personality senses somewhat coincides, in our opinion, with the process of cultural cultivation of a person which will become in the near future increasingly dynamic, will gain new material and spiritual forms and the content of its development. In the end, it should be emphasized that in the modern world with former restrictions being removed the field of social action expands, namely, social activeness and social dialogue are gradually becoming the leading forms of the relations of a modern person, in particular that of "Homo educandus".

Today we can state certain contradictions in the manifestation of young people's social activeness. Firstly, the socialization of young people is not always purposeful and guided. Secondly, social activeness of an individual as a source of communicative action is impossible without a dialogue (interpersonal, social and group, etc.) in the space of the mechanism of understanding, the growth of activeness and the implementation of dialogicity. Thirdly, today there are almost no existing conceptual provisions that could be applied in modern science for modelling and designing the development of individual's social activity in the cultural and educational space.

The review of recent studies and publications on the issue shows that activeness as a phenomenon occupies a prominent place in the humanities. Moreover, the term "activeness" is used either alone or in various wordcombinations so often that in some cases it becomes so common and ordinary that it forms independent concepts, for instance: an active person, an active life position, an activist, an active element of the system, active student, active public position, active learning, etc. 
The term "activeness" is associated in humanities with the active attitude of a man towards the world, with his/her ability to produce socially meaningful changes in the material and spiritual environment, based on the acquisition of the socio-historical experience of mankind, that is, social activeness coincides essentially with world outlook (V. Kosovets, H. Kodzhaspirova, V. Radul). According to pedagogical dictionaries and encyclopedias, human activity is manifested in creative activity, volitional acts, communication. The orientation of active actions can be useful or asocial, since human actions can have humane or inhumane goals. Some researchers (for example, H. Kodzhaspirova) distinguish between social activeness and learning activeness. Thus, the social activeness in the pedagogical dictionary of $\mathrm{H}$. Kodzhaspirova and A. Kodzhaspirov is a generic concept in relation to superordinate concepts: socio-political, labor, cognitive, etc. As the dictionary explains, social activeness is realized in the form of socially useful actions, under the influence of motives and stimuli which are based on socially significant needs [1, p.14].

It is important for our study to understand that the subject - the bearer of social activeness - is a person, a social group and other communities. The development of social activeness as a social property of the individual occurs through the system of human connections with the surrounding social environment in the process of cognition, activity and communication. We also emphasize that social activeness is a dynamic entity and can have different levels of manifestation, different levels of social activeness depending on the relationship between the social responsibilities of the individual in socially significant activity and subjective orientations concerning activity.

Thus, paper aims to reveal and justify the constructive potential of social dialogue in the development of young people's social activeness.

\section{Research methods}

The interdisciplinary synthesis and analysis of cultural and educational practices should be considered as the key methodological principle, within which the phenomenological approach allows to compare social activity and dialogicity as manifestations of young person's properties in the process of dialogical cultural and educational interaction, methods of interpretation, comparative analysis, etc. that helped to identify the essence and specifics of the subject phenomena. Experimental verification of the main results was carried out on the basis of content analysis and techniques of collecting empirical data (testing, survey, observation, activity products analysis, introspection, etc.).

Before providing dialogical support for social activeness, namely, dialogical strategies, we reasonably presented the results of our reflections in favor of a dialogue about the higher senses of human being and turned to values - universal guidelines for humanity. With the help of an express survey we built up a model of the "chain of values" and found some positions of students regarding different levels of their aspirations. The study was carried out with the support of the Psychological Center of the Educational and Scientific Institute of Socio-Pedagogical and Artistic Education of the Melitopol State Bohdan Khmelnytskyi Pedagogical University, and founded at the University Department of Practical Psychology students" academic club "Ordo amoris". The experiment involved 90 students majoring in "Psychology" and "Practical Psychology" (32 students from Ukraine and 58 respondents from European countries).

The results of the survey allowed us to determine dominant value groups. The first group of values turned to be vital (biologically vital) values, herewith, if we transfer the understanding of values into a plane of value orientations, then their name will be different - the vital and cultural values (A. Furman): 1) physiological existence, provided by the absence of natural disasters, epidemics, etc. 2) the balanced state of ecological comfort and ecosystem's adequate impact; 3) informational and spatial comfort (protection from "stress"); 4) the possibility of labor, educational, everyday life balanced state and the ratio of physiological and motor factors of life activity; 5) the continuation of the family line as human biological and moral aspiration.

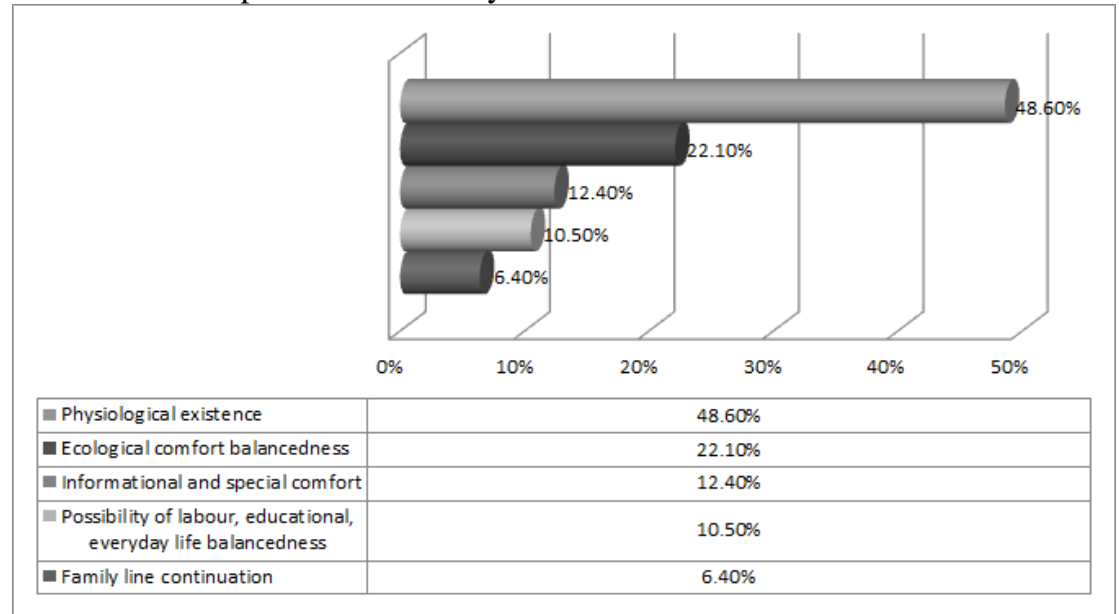

Fig.1 Diagnostics of vital and cultural values 
In this sense, the results of our express survey demonstrate quite apparent coincidence of the assessment of these problems' importance. However, the answers of students who studied examples of value preferences of European countries' students, learned about them when studying English, Polish, German, Bulgarian and other languages were characterized by a higher level of intelligence, spiritual orientation, socially active life position. The students gave examples that were significantly typical for European youth, namely, they showed calm attitude to sexual problems, higher awareness of the problems in this field, etc.

Ethological and behavioral, ethnic values (psychological) are directly related to introducing a person in one or another group for performing emotional contacts $(28.6 \%)$, for optimization of the personal space $(12.8 \%)$, the pace of life $(8.3 \%)$, the implementation of ethnic identity (37.6\%) and inclusion in everyday life, traditions, customs and ecological culture (12.7\%). Compared to the previous block, these values are not so impressive that it could be possible to compare and draw conclusions but there is still a clearly observed indifference in respect to their acquisition. This means that the desire for a dialogue, social activeness, acquiring European values with such passivity will not be provided by a cognitive base, there will be no intellectual exchange of knowledge about one's nation and it will be difficult to reach humanity as a universal.

The next block of values chain concerns sociopsychological, labor, economic and other aspirations of the individual which are unfolded in the system direction or in a complex and holistic manner in all directions of its improvement (homo faber, homo economicus, homo socialis, homo femilis, etc.). Examples of English texts and stories of European countries' young people convince us that the holistic person of culture in modern interpretation is not the qualities or functions of a person, not the sum of virtues and standards of etiquette, but a person who is capable of the most effective and constructive implementation of his/her individual abilities, intellectual, spiritual and creative potential. The dialogue does not only lead to the understanding and acceptance of certain behavior norms, certain stated limitations (for example, any creative initiative in the natural boundaries and elaborated by the society moral and ethical norms, principles and rules of life are allowable), but also at the metaphysical level it unites people in search for common mutual understanding and responsibility to nature, people, God. The results of the analysis of the express survey show that there are significant differences in the responses to the questions of students and young people in European countries and students of our universities within this block, on the one hand, student activists and students who are passive in determining their life position or, at least, they do not show it, on the other hand.

The analysis of the respondents' values according to Sh. Schwartz's method involves the construction of the second order indices for each of the 10 types of value orientations. In this case, the respondents' answers are corrected by deducting from the initial score the average point for all answers of the respondent in order to get rid of his/her responding style, individual inclination to overestimate or underestimate his/her scores. The obtained "centralized" value resulting from such a correction is, in fact, an assessment of the relative importance (priority) of one or another value in the value hierarchy of each respondent.

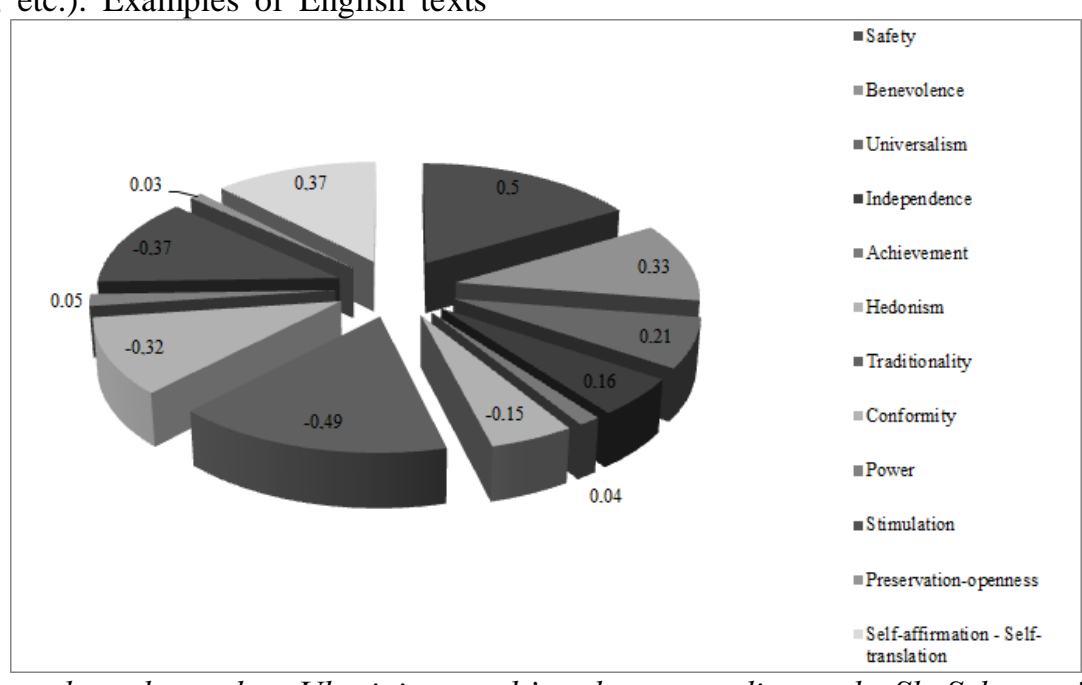

Fig. 2. Research on the modern Ukrainian youth's values according to the Sh. Schwartz's technique

The value orientations on safety and benevolence, independence and achievements are of the highest priority for the Ukrainian youth. The place of the universalism value turned out to be unstable. The lowest place in the values hierarchy is stimulation. In general, the Ukrainian youth is characterized by a significant openness to new experience and orientation to their interests, which manifests itself in their greater pursuit of the values of achievement, hedonism and stimulation. At the same time, the dynamics in time enhances the tendency of increase in the self-affirmation values' importance. 


\section{Discussion}

The justification of our scientific results is incomplete if their interpretation is not confirmed by psychological theoretical research studies. Thus, social activeness is considered to be significant in psychological studies ( $\mathrm{P}$. Hurevych, V. Kosovets) where it is social and psychological activeness that appears as an ability of an individual and collective subject for optimal organization of joint activity. The dictionary explains that the realization of positive values takes place in the process of interaction of people involved in elaborating productive ideas necessary for the successful society functioning. And if social and psychological activeness is reduced to such a narrow meaning as an ability, the term "activeness" which is interpreted as an active state is broader [4, p. 293]. At the same time, we share the opinion of V. Kosovets who understands social activeness as a stable personal entity that characterizes a young person as a social being who has a clear personal orientation, a worldview as a system of knowledge and beliefs, has his/her own position, interacts with the environment [2, p. 8].

In our opinion young people's social activeness involves the following stages: 1) spontaneous, unregulated and unorganized social activeness; 2) formation of an organized system of social activeness development; 3) praxeological orientation of young people's social activeness. Herewith, each stage has certain features that are conditioned by political, social, economic and other factors, as well as by the development of the public educational movement, educational and teaching work.

The term "social activeness" is also clarified in the studies of Polish scientist P. Shtompka. Thus, in his book "Sociology. Analysis of contemporary society" he devoted a whole section to the interpretation of this concept. In his opinion, the society itself is already an activeness, activity of people: "There is no society without active people. Everything that exists in a society is either manifestation or consequences of human activeness. ... The most obvious, apparent manifestation of human activeness is the movement" [8, p. 41-42]. He divides human activeness into several levels, the first of which is elementary in terms of physical activeness. P. Shtompka suggests using the sociological term "behavior" to describe the activeness based on certain movements.

Thus, we believe that the development of individual's social activeness takes place in various forms of activity, in various forms, subjected to changes in external and internal sources, and is given in the interpretation of the values of symbolic communities, which is manifested in spiritual and practical activity, and interaction with the environment.

At the level of methodological requirements, in our opinion, in general terms, social activeness can be defined as a combination of individual's efforts aimed at transforming social reality and oneself as a subject. On this basis, young people's social activeness and social dialogue become important structures in the cultural and educational space of a higher educational establishment.
Social activeness is determined by the social activity: this concept is "at the same time the process of social activity characterized by intensity, quality, novelty, creativity, success, content filling and can occur under certain conditions and in certain situations". Since social activeness of young people is interpreted vaguely and multifacetedly (as a state of the subject in the process of interaction with the society, as a kind of activeness in social communicative systems, etc.), it is necessary to consider it precisely in the plane of a social dialogue, which expands activeness to individual's communicative competence.

According to many scholars (V. Tsvykh, D. Nelipa, V. Yevtukh, V. Sahatovskyi et al.), social dialogue is a necessary condition for the development of interpersonal, intergroup, interstate ties and relations. In their works, social dialogue as a special form of a dialogue appears as a relationship between two or more subjects, the exchange of opinions, primarily on socio-political themes, the search for effective ways of their use [7], as a special socio-cultural phenomenon, if it is reflected in the essential and substantive characteristics, since it falls under the definition of everything that is social (from Latin "socialis" - general, social is the name of all interhuman, i.e. of that which is connected with the common life of people, with different forms of their communication, firstly, of what belongs to the society and community, which has social and common character) [6, p. 429-430].

The researchers dealing with the issue of the social dialogue (M. Vak, A. Hriaznov, D. Nelipa, V. Tsvykh and others) note that a dialogue is, first of all, the activity of subjects who occupy certain positions unfolding in the certain communication space, and, therefore, the subjects enter the dialogue as bearers of certain values that they protect in the constant reproduction of the situation of seeking the truth and deepening mutual understanding, discussing and accepting the values of each other. In the process of holding a dialogue each subject, seeking new means for expanding his/her opportunities for effective participation in this process uses a certain system of proofs, increases the field of his/her evidential intelligence, raising "himself/herself over himself/herself" [7]. The subject of the dialogue occupies there a position inherent in the individual with a developed consciousness and self-consciousness, with a certain level of selfdetermination, which characterizes the historical state of the society development, providing the appropriate possibilities of person's individualization and socialization. It is this aspect that gives us grounds for analyzing the dialogue as a factor of facilitating young people's activeness and expanding it on the basis of social activeness.

Since young people are subjects of cultural and educational environment, the dialectics and dynamics of social activeness and dialogue take place in the institutional and subjective plane of this space.

Thus, the dialogue is a movement in search for the truth from the concrete to the general, which is carried out due to solving some complex contradictions of the inter- 
nal (for each subject) and external (in the very space of dialogue) planes. The space of the dialogue, its content, subjects and actions are different. Quite specific is, for example, a dialogue, carried out as a means of scientific research. That is why the allocation of a dialogue beyond the concrete forms and types of manifestation and putting it into a single space of communication, and considering it as a special phenomenon allows us to evaluate it both in its social meaning (as a type of communication) and as a factor modelling the subjects of a particular historical reality relationships. Then the focus of attention shifts to the genesis of the dialogue in connection with its role in the deployment of certain systems of interaction between the subjects which self-identify, implement and restore the relationships that historically correspond to a certain level of the society development, social consciousness, the subject itself. Any dialogue requires the subject's social activeness. In numerous studies, a dialogue is interpreted as such an exchange of information, which simultaneously fulfills two conditions: the existence of the process of information exchange between the subjects; the presence of at least two participants in the dialogue. Violation of the first condition denotes the absence of the dialogue at all, and the violation of the second one actually converts the dialogue into a monologue. We believe that regardless of the type of a dialogue it primarily includes generic properties: informative and existential interaction between the parties of communication through which the understanding becomes possible. At the same time, the issue of the informative component is not intended to emphasize the information itself as systematized messages, but to understand the informativeness in a broad sense (the exchange of messages, information, knowledge-laws, senses). In this sense it enhances social activeness, which is also realized at different levels of the society's existence: at the micro level (in individual communication); at the macro level (in the communicative interaction of social groups, civil organizations, political movements and parties); at the mega-level (in the dynamic stabilization of the social system and even in the dialogue of social systems, in the dialogue of cultures, civilizations).

It is difficult to overestimate the role of freedom as the goal of human life activity, which is gained, in particular, by social activeness. However, each participant of the dialogue has some autonomy that is incompatible with dictates, relationships of domination-subordination. At the same time, the more participants announce their judgments, the more chances of being efficient the dialogue has; the more ideas are offered for discussion, the greater the possibility is that there will be the one among them deserving attention. Consequently, the indispensable activeness in the dialogue acquires dimensionality and it can be of great importance in providing social stability of the society, its dynamic balance.

We are convinced that equal participation of subjects in a social dialogue makes social activeness sustainable; existing constitutional and legal, historical and cultural forms in the social dialogue direct social activeness to the constructive development of social processes; disclosure of social activeness in the dialogue prevents social tensions, social conflicts; with the help of the dialogue socially active youth will acquire such abilities as creativity (ability to ask questions, to prove and refute statements, to conduct a talk, to perform heuristic tasks, to increase the quantity and quality of creative elements in educational works, to increase the degree of integration when acquiring subject fields); cognitiveness (depth, completeness of the educational product, quantity and quality of subject knowledge, conformity of educational products with the topics of the research); organizational ability (ability to set goals, to create an educational product close to the student's personal goals, ability to reflect, etc.).

Particular attention should be paid to the analysis of social activeness as a desire for dialogue and communication. There are different justifications for the anthropological favorability of communication with other people in different psychological approaches: a) communication conditioned by a person's bodily needs (W. McDowgall, K. Hull, B. Bekhteriev, V. Viliunas et al.); b) communication caused by the influence of certain individual properties: aggression, need for power, leadership, etc. (personality reductionism - A. Adler, T. Adorno, H. Teshfler, D. Campbell et al.); c) motivation in communication appears as a function of the immediate environment and ethno-social affiliation (H. Murphy, J. Mead, R. Mills et al.).

Since it is referred to a certain measure of young people's social activeness one should pay attention to the works of philosophers who investigated the factors that connect human consciousness with the active (innovative) aspiration for the Other (A. Yermolenko, E. Levinas, P. Riker, V. Tabachkovskyi et al.). Based on the analysis of these works and the ideas of V. Tabachkovskyi it is possible to outline the contours of young people's active desire for communicative action with other person, under condition of which communication from the anthropological point of view appears as a way of individual's creative self-affirmation; as an innovative mechanism for improving the ways of multicultural diversity comprehension [5]; the recognition of the humility and affinity of the individual with the entire human and non-human world [3, p. 118]; as a "sovereignty" of another person (E. Levinas); as a space of orientation at a consensual and communicative ethics of responsibility (I. Kant, K.-O. Apel, A. Yermolenko); the process of the "culture of mind" growing (I. Kant) as an ability to understand another person; a way of enriching the common worldview, existentially-communicative activeness and competency. Since both social activeness and dialogue have their own manifestations in a certain action, it is necessary to extrapolate them to the structural components of the action itself, instead of the activity components. In this way, this structure will look, in our opinion, as follows:

1) value-based and motivational, that is the component that causes, initiates and directs an action; 
2) informational and regulatory, which contains a multitude of different ideal programs and models of action;

3) operational, where motives turn into subject's physical actions;

4) resultant, where the subject's actions are objectified, acquire a certain form of existence;

5) further reflective and evaluative component occurs, where goals and results are compared, a new situation appears that causes a new cycle of activity.

\section{Conclusions}

It was the above mentioned structural components according to which we observed the dynamics of students' social activeness in the course of dialogical interaction, which was assessed with the help of the techniques developed by V. Doskin, N. Lavrentiev, V. Sharai, M. Myroshnykov, N. Kurhanskyi, as well as on the basis of questionnaires of T. Liri, V. Shutts, K. Thomas et al.

The analysis of empirical facts and the interpretation of the experiment results revealed the existence of certain trends in the manifestation of students' social activeness before implementing some dialogical strategies of cultural and educational space and after methodological assistance

\section{REFERENCES}

1. Kodzhaspirova, G. M. \& Kodzhaspirov, A. Yu. (2005). Slovar po pedagogike [Dictionary of pedagogy]. Moscow: IKTs «MarT»; Rostov n/D: Izd. tsentr «MarT» [in Russian].

2. Kosovets V. I. (2009). Rozvytok sotsialnoi aktyvnosti molodi $\mathrm{v}$ umovakh sotsiokulturnoho seredovyshcha sela [Development of young people's social activeness under conditions of the countryside environment]. Extended abstract of candidate's thesis [in Ukrainian].

3. Troitska, T. S. (Eds.). (2012). Liudynomirnist harmonizatsii kulturnoosvitnioho prostoru osobystosti: metodolohiia, ekspertyza ta psykholoho-pedahohichni retseptsii [Human-relatedness of individual's cultural and educational space harmonization: methodology, expertise, psychological and pedagogical receptions]. Melitopol: Vydavnychyi budynok MMD, 2P2 [in Ukrainian].

4. Gurevich, P. S. (Eds.). (2007). Psikhologicheskii slovar [Dictionary of psychology]. Moscow: OLMA Media Grupp, OLMA PRESS Obrazovanie [in Russian].

\section{ЛІТЕРАТУРА}

1. Коджаспирова Г. М. Словарь по педагогике / Г. М. Коджаспирова, А. Ю. Коджаспиров. - М.: ИКЦ «МарТ»; Ростов н/Д: Изд. центр «МарТ», 2005. - 448 c.

2. Косовець В. І. Розвиток соціальної активності молоді в умовах соціокультурного середовища села: автореф. дис. на здобуття наук. ступеня канд. пед. наук: спец. 13.00.05 "Соціальна педагогіка" / В. І. Косовець. - Нац. пед. ун-т ім. М. П. Драгоманова. - Київ, 2009. - 23 с. and dialogical support. The source of social activeness is an operational and activity-based component with a partial presence of informational and resultant ones. This can be explained by the epistemological limitations of knowledge, values and senses.

Inclusion of students in the process of cultural and educational interaction within the framework of dialogical strategies provided substantial content to their efforts regarding participation in social events, volunteer work for the values- and sense-based presentation aspirations, articulation, and defense of their interests. Thus, dialogical support provides the significance of social activeness itself as a phenomenon, as a way of increasing the subjectivity of the individual, his/her sociability, selfdevelopment, and society's social stability. The dialogue in the value-based and motivational component appears to be the main principle of the desire to understand the world and transform oneself, in informational and regulatory as a way of enriching social activeness with intelligence and ethical responsibility, in the operational and resultant - as a construct of convergence to the praxeologicity of social activeness. Elaboration of mechanisms for such convergence can be a prospect for further research.

5. Tabachkovskyi, V. H. (2005). Filosofskoantropolohichna refleksiia ta ii osvitianske zalomlennia [Philosophical and anthropological reflection and its educational focus]. Filosofiia osvity - Philosophy of education, 2, 110-126 [in Ukrainian].

6. Hubskyi, Ye. F. (Eds.). (2002). Filosofskiy entsiklopedicheskiy slovar [Encyclopaedic dictionary of philosophy]. Moscow: INFRA-M, 429-430 [in Russian].

7. Tsvykh, V. F. \& Nelipa, D.V. (2006). Sotsialnyi dialoh: osnovni pidkhody do vyznachennia [Social dialogue: main approaches to defining]. Visnyk Kyivskoho natsionalnoho universytetu imeni T. Shevchenka. Seriia: Filosofiia. - Bulletin of Kyiv National University named after T. Shevchenko. Series: Philosophy, 81-83, 182-185 [in Ukrainian].

8. Shtompka, P. (2005). Sotsiologiia. Analiz sovremennogo obshchestva [Sociology. Analysis of contemporary society]. (S. M. Chervonna, Trans). Moscow: Izdvo «Logos» [in Russian].

3. Людиномірність гармонізації культурноосвітнього простору особистості: методологія, експертиза та психолого-педагогічні рецепції: [монографія] / за заг.ред. Т.С. Троїцької. - Мелітополь: Видавничий будинок ММД, 2П2., 2012. - 378c.

4. Психологический словарь / под общ. науч. ред. П. С. Гуревича. - М.: ОЛМА Медиа Групп, ОЛМА ПРЕСС Образование, 2007. - 800 с.

5. Табачковський В. Г. Філософськоантропологічна рефлексія та іï освітянське 
заломлення / В. Г. Табачковський // Філософія освіти. - 2005. - №2. - С.110-126.

6. Философский энциклопедический словарь. М.: ИНФРА-М, 2002. - 576 с. - С. 429-430.

7. Цвих В. Ф. Соціальний діалог: основні підходи до визначення / В. Ф. Цвих, Д. В. Неліпа // Вісник
Київського національного університету імені Т.Шевченка. - 2006. - Серія:Філософія. - Вип.81-83. C.182-185.

8. Штомпка П. Социология. Анализ современного общества: пер. с польск. С. М. Червонной / П. Штомпка. - М.: Изд-во “Логос" , 2005. - 664 с.

Катерина Сергї̈вна Аверіна, кандидат педагогічних наук, доцент кафедри соиіальної роботи, соиіальної педагогіки та дошкільної освіти, Мелітопольський державний педагогічний університет імені Богдана Хмельницького, вул. Гетьманська, 20, м. Мелітополь, Украӥна,

Олена Михайлівна Троӥцька, кандидат філософських наук, дочент кафедри філософії, докторант, Національний педагогічний університет імені М. П. Драгоманова, вул. Пирогова, 9, м. Київ, Украӥна

\section{СОЦІАЛЬНА АКТИВНІСТЬ МОЛОДІ: ДІАЛОГІЧНИЙ \\ СУПРОВІДУ КУЛЬТУРНО-ОСВІТНЬОМУ ПРОСТОРІ}

Актуальність статті зумовлена проблемною ситуацією, що склалася в культурно-освітньому просторі через те, що незмірно зростає активність молоді як суб'єкта цього простору, і недостатнім залишається рівень розуміння іiї значущості, сутності, можливостей і меж. Активність як феномен посідає чільне місце у гуманітарних розробках, в яких вона тлумачиться багатозначно і постає компаративно як така, що ототожнюється з іншими феноменами або явищами. Аналіз дослідницької літератури вимагає не тільки коректно визначити сутність соціальної активності, а й встановити вплив на ії формування чинників культурно-освітнього простору, до яких слід віднести діалог як інформативно-екзистенціальну взаємодію суб'єктів з метою розуміння. На основі міждисциплінарної методології, феноменологічного підходу, методів дослідження (інтерпретація, порівняльний аналіз, синергетичний та ін.) та методик збору емпіричних даних (тестування, опитування, спостереження, інтроспекція тощо) установлена залежність розвитку соціальної активності Ното educandus від участі в розгортанні діалогічних стратегій культурно-освітнього простору. Діалогічний супровід представлено як підсилення соціальної активності (сукупність зусиль особистості щодо перетворення себе і соціуму), що відбувається за компонентами дії суб'єкта, за стадіями розгортання соціальної активності, за різними рівнями розвитку суспільства, за зростанням рівня свободи особистості.

Ключові слова: взаємодія, дія, діяльність, розуміння, соціальне, спілкування, суб'єкт, цінності.

Submitted on May, 4, 2017

Reviewed by Doctor of Pedagogy, prof. L. Moskaliova 